\section{Revista de la \\ Universidad del Thulia}

Fundada en 1947 por el Dr. Jesúns Enrique Lossada

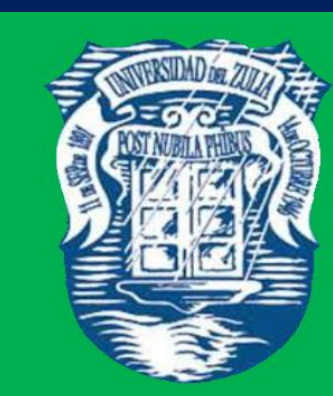

Ciencias del

Algreo

Ingemieria

y Teemología

\section{Aกัต 11 No 29}

Enero - Abril 2021

Tercera Época

Maracaibo-Venezuela 


\title{
Cluster Technology as a basis for the competitive development of industries in Russia
}

\author{
Viktoriya V. Prokhorova* \\ Elena I. Artemova ** \\ Marina B. Miroshnichenko *** \\ Avanesova Rita Rafaelovna **** \\ Chazhaeva Maynat Mausurovna $* * * * *$
}

\begin{abstract}
In the context of globalization (Acuña, 2011) and the pressure of sanction on the national economy of the Russian Federation, the problem of the provision of competitiveness of industrial companies stands out. Economic policy in the national economy, oriented more towards the raw material component, has ceased to correspond to the modern requirements of society. In relation to this provision, new state priorities appeared, focused on improving scientific and technological development, innovation and modernization of the industrial complex, etc., which, in turn, requires the development of new mechanisms and appropriate instruments for the regulation of economic relations in the industrial sector, and the implementation of government support for the industry. However, it must be recognized that federal and regional sustainable development programs and industrial management mechanisms used in modern realities are not effective enough because they generally aim at the isolated solution of local problems. It is indisputable and obvious to all that it is impossible to reach the level of global competition without the progressive and competitive development of the main industries. One of the most constructive solutions to this problem is the cluster approach. Our country has some experience and achievements. So in 2012, employees of the Ministry of Economic Development of the Russian Federation developed a group-oriented program, the implementation of which involves twenty-five industrial groups. Cluster technologies allow the creation of synergistic and multiplier effects, which, in the end, is a boost for the development of economic growth. But despite all the preferences of the cluster approach, national cluster technologies were unable to implement their advantages, indicating the continued stagnation of industrial production. In this way, the purpose of this research is to study the possibilities of effective use of cluster technologies in the Russian industrial field.
\end{abstract}

KEYWORDS: Economic crises, sanctions, global competition, industrial complex, strategy, cluster technologies.

*Doctor of Economic Science, professor, Kuban State Technological University, Russia, prokhorova766745@mail.ru

${ }_{* * *}^{*}$ Doctor of Economic Science, professor, Kuban State Agrarian University named after I.T. Trubilin, Russia.

${ }^{* * *}$ Assistant, Kuban State Technological University, Russia.

${ }^{* * * *} \mathrm{PhD}$ in Economics, associate professor of the Belorechensky branch at the FSBEI HE "Adygea State University".

${ }^{* * * * *} \mathrm{PhD}$ in Economics, Associate Professor, FSBEI HE "Chechen State University".

Recibido: 08/01/2020

Aceptado: 12/02/2020 


\section{Tecnología de Clúster como base para el desarrollo competitivo de las industrias en Rusia}

\section{RESUMEN}

En el contexto de la globalización (Acuña, 2011) y la presión de sanción sobre la economía nacional de la Federación de Rusia, destaca el problema de la provisión de competitividad de las empresas industriales. La política económica en la economía nacional, orientada más hacia el componente de materia prima, ha dejado de corresponder a los requisitos modernos de la sociedad. En relación con esta disposición, aparecieron nuevas prioridades estatales, centradas en la mejora del desarrollo científico y tecnológico, la innovación y modernización del complejo industrial, etc., lo que, a su vez, requiere el desarrollo de nuevos mecanismos e instrumentos apropiados para la regulación de las relaciones económicas en el sector industrial, y la implementación del apoyo gubernamental para la industria. Sin embargo, debe reconocerse que los programas federales y regionales de desarrollo sostenible y los mecanismos de gestión industrial utilizados en las realidades modernas no son lo suficientemente efectivos porque, por lo general, tienen como objetivo la solución aislada de problemas locales. Es indiscutible y obvio para todos que es imposible alcanzar el nivel de competencia global sin el desarrollo progresivo y competitivo de las principales industrias. Una de las soluciones más constructivas para este problema es el enfoque de clúster. Nuestro país tiene cierta experiencia y logros. Entonces, en 2012, los empleados del Ministerio de Desarrollo Económico de la Federación de Rusia desarrollaron un programa orientado a grupos, en cuya implementación participan veinticinco grupos industriales. Las tecnologías de clúster permiten crear efectos sinérgicos y multiplicadores, que, al final, es un impulso para el desarrollo del crecimiento económico. Pero a pesar de todas las preferencias del enfoque de clúster, las tecnologías nacionales de clúster no pudieron implementar sus ventajas, lo que indica el estancamiento continuo de la producción industrial. De esta manera, el propósito de esta investigación consiste en estudiar las posibilidades de uso efectivo de las tecnologías de clúster en el ámbito industrial de Rusia.

PALABRAS CLAVE: Crisis económicas, sanciones, competencia global, complejo industrial, estrategia, tecnologías de clúster.

\section{Introduction}

There are many scientific works in the specialized literature on competitive advantages of business entity development in the industrial sphere and industrial cluster creation on their basis. However, we did not find any works that provide a 
systematic idea of cluster strategy use to form the competitive development of the industrial complex as a whole and its individual industries and enterprises. As a rule, researchers pay more attention to certain aspects of industrial cluster production and financial activities, ignoring the complex problems of a strategy development for business entity competitiveness increase within the framework of the created cluster formations.

Based on this situation, the goal was set during writing the article, - to propose and justify a conceptual scheme for analysis and diagnosing of economic entity competitiveness at different stages of their development; to develop the contours of the organizational and economic mechanism for the formation of an industrial cluster to increase the competitive advantages of specialized enterprises, taking into account internal and external system-forming factors formed by two structural elements, providing:

- The modeling of an optimal organizational and economic structure of cluster formation and the degree of development of its production and technological infrastructure;

- the development of an adaptive algorithm mediating the technical and economic dynamics of the cluster development and the competitiveness of all its participants based on effective tools (road quotas for cluster development), the sources of financing activities (PPPs, private investments, outsourcing, etc.)

In our study, we proceed from the fact that the tasks of industrial enterprise competitiveness growth provision are directly associated (methodically) with the search for effective mechanisms of their growth, as well as with the diagnosis of their competitiveness level.

We believe that nowadays the cluster approach acts as the optimal approach to increase the competitiveness of domestic diversified enterprises of the industrial complex, because it synthesizes the provisions of other concepts of new sources of competitive advantage development with most priority from the positions of previously identified competitive dominants. 
All this allows us to consider the cluster strategy as the most promising organizational and managerial mechanism for the development of competitive advantages of the industrial complex regional enterprises.

\section{Research Methodology}

The theoretical and methodological basis of the study was the conceptual provisions of competitive development theory of Russian and foreign scientists, a number of the latest theoretical and applied studies on the problems of industrial enterprise competitiveness increase in the framework of industrial cluster development and territorial cluster formations.

In the process of establishing, analyzing and diagnosing of factors that have a multidirectional effect on the growth of industrial enterprise competitiveness, they used the methods of comparison, expert assessment and classification.

The empirical base of this scientific article was the statistical materials of the Federal State Statistics Service of the Russian Federation, as well as the industrial statistics on production and financial activity of economic entities of the depressed republics in the North Caucasus.

\section{Research Results}

Within the conditions of constantly increasing competition, state support for cluster technologies and the initiatives for the participation in cluster technologies should act as the priority area of state industrial policy. In our opinion, only such an approach will create incentives for the required structural changes, increase the competitiveness of diversified enterprises in the industrial complex and act as an effective tool for innovative long-term development.

It is recognized that mechanical engineering in any country is regarded as a strategically significant branch of industrial production, since the further growth and the quality of manufactured industrial products, as a rule, depend on the level of its development. It is clear that engineering is a key industry sector and only it is able to 
set the main tone in the implementation of the innovation scenario within the national economy.

Indeed, only this industry can provide all the necessary equipment to industrial enterprises in the field of raw material processing and industrial production, which will increase the country production potential. It should also be noted that the creation of new (high-quality) types of industrial equipment makes it possible to reduce the material and energy intensity of industrial product significantly, which will effectively affect the economy of the respective industries (Ansov, 1989; Azoev, 2012; Misakov et al., 2016).

The illiterate privatization affected the state of manufacturing industry quite negatively, especially in mechanical engineering. The industry transition to market relations was also accompanied by the excess of production capacity, a high share of technological equipment with moral and physical depreciation (more than 70\% are 20 years old or more), high production costs due to unacceptably low productivity of equipment, the lack of modern production infrastructure, an acute deficit of credit and investment funds, low level of cooperation between enterprises in the engineering industry.

All this required the development of urgent measures to increase the competitiveness of industrial enterprises intended to produce high-tech equipment.

It should be noted that in recent years they created several fairly large-scale industrial clusters, within the framework of which there is a significant consolidation of assets of industrial enterprises engaged in mechanical engineering. There has also been the tendency to increase financial support for the transport sector, power engineering, aircraft manufacturing and other high-tech sectors of the engineering industry, and stable budget subsidies have been established for production infrastructure.

Under these conditions, there is no longer any need to prove the advantages and importance of clustering for the successful solution of the main problems in the areas of innovative and technological development of the national economy. The cluster approach allows to compensate for the insufficiency of the main types of resources, 
including such as raw materials, energy, innovation, etc. (Aloeva \& Misakov, 2013; Korchagina, 2003; Basyuk et al., 2016).

In order to make engineering become the driver of the industry and the source of renewal and modernization of the industrial sector and be able to transfer the entire industry to an innovative development path, it is necessary to develop a set of targeted government support measures for a radical restructuring of the industry. Under these conditions, it is advisable to form 6-8 large-scale engineering clusters in the country. The rational use of a combination of external and internal system-forming factors allows us to generate a cluster effect, which contributes to the creation of new and activation of existing competitive advantages, the formation of modern infrastructure and even active interaction in the cluster formation of enterprises that are direct competitors (Afashagova et al., 2014; Artamonova, 2013; Prokhorova et al., 2018).

It should be noted that within the framework of the cluster, the process of constant modernization of technologies and products is inevitable, the life cycle of industrial products, etc. is shortened, which, ultimately, has a positive effect on the final results.

All varieties of industrial clusters can be reduced to two main types:

- The clusters formed on the basis of large industrial production structures;

- The clusters formed in new sectors of the economy (Lagodyuk, 2010).

As a rule, the clusters included in the first group, implement process innovations in the form of new production technologies, and the modern methods of industrial production.

The clusters of new branches of the industrial complex are engaged in product innovation and in the development of new industrial product exclusively.

The financial and investment basis of the cluster is the consolidated activities of various investment funds, banks and other specialized financial structures.

There are sufficient conditions for cluster strategy application in the republics of the North Caucasus. There are several large enterprises of the engineering industry, in particular, mining, metallurgical, petrochemical, energy, building materials ...

The analysis of industrial development economic indicators in the depressed republics of the North Caucasus allows us to note that, although the volume of regional 
production has been constantly growing since 2010 in absolute terms, at the same time the annual growth rate falls. It is also appropriate to say that the annual growth of industrial volumes with a constant (annual) reduction of workers allows us to talk about some labor productivity growth (Kushbokova et al., 2009; Rzhevskaya, 2012; Zakharova et al., 2015).

But substantial investment is very necessary for the full revitalization of industry.

Foresight analysis made it possible to verify once again that the region has no prospects for competitive advantage development, because there is no developed production and innovation infrastructure, industrial and scientific potential are not involved, which raises concerns about the possibility of investor attraction to implement the necessary technical and technological modernization.

Depending on the characteristics of the present integration ties, the entire set of industrial clusters is divided into three groups: aggregated, mixed and specialized clusters.

The first group of cluster development based on the principles of outsourcing is engaged in the production of industrial products that meet the needs of the target market for a number of parameters, including such as price, quality and the number of technical specifications.

The second group of cluster structure is built on the principle of horizontal integration. It is more effective than the aggregated structure of clusters, because the competitive environment formed inside such cluster formations has a much stronger positive effect on the development of the overall industrial cluster competitiveness.

The development of the industrial cluster in a depressed and labor-intensive region is impossible without an innovative production infrastructure. This requires large-scale investments, which are absent in the depressed region. They can be found only on the principles of partnership between the public and private sectors.

This approach forces the mobilization of all financial, economic, technical and other resources of the public and private sectors within a single industrial cluster. At that, if necessary, it helps to maintain the state ownership of the most significant 
production and social infrastructure objects (Bryazgina, 2016; Vinokurova, Yudanov, 2012).

The development of competitive advantages and their implementation allows the most effective implementation of the import substitution policy.

In our opinion, the strategy of building up the competitive advantages of the industrial cluster is, ultimately, the system of effective measures for the sustainable development of cluster institution.

An approximate algorithm for competitiveness increase strategy in respect of industrial cluster formation is given below.

1. The analysis of the external and internal environment factors of the industrial cluster is performed at the first stage.

2. The second stage is the refinement of goal formulation for competitiveness growth.

3. They develop and select the strategic alternatives for the formation and development of the cluster industrial enterprise competitive advantages during the third stage.

4. They determine the target indicators to assess the provision of specified parameters at the fourth stage.

5. The priority intracluster areas (projects) are selected during the fifth stage, in particular, the modernization of production, the development of a modern production infrastructure, etc.

6. They perform the optimization of cluster institution, develop optimal diversified product programs of multidirectional cluster enterprises during the sixth stage.

7. During the seventh stage, they develop the system of mutual coordination within the cluster institution in order to increase the effectiveness of all its participants.

8. The monitoring and control of the strategy involvement is performed during the final (the eighth) stage to increase the competitiveness of the industrial cluster.

This algorithm is not final. Actually, it can be of 5 stages, and of 10 stages. This is not fundamental - the main thing is to cover all procedures, from the formulation and goal setting, to the development and implementation of cluster projects. 


\section{Conclusions}

Thus, it can be noted that the tasks of an industrial cluster competitiveness increase are methodologically associated with an effective mechanism development for its formation, as well as with cluster member competitiveness diagnosis. The clustering of diversified industrial enterprises of various industries makes it possible to influence both the determinants of the competitive position of all its participants and the cluster as a whole, as well as the determinants of competitive forces, because these institutions also include government agencies that can create institutions that affect the business environment of industrial cluster effectively.

Under the conditions of Russian reality, state support for cluster initiatives should be considered as a priority for the implementation of regional industrial policy, because it can mobilize the necessary structural changes, increase the competitiveness of diversified enterprises in various industries and act as an effective tool for the innovative development of depressed republics.

We have proposed a modified algorithm to optimize diversified business entities by their incorporation into large cluster industrial groups that can be successfully (and easily) used in the development and implementation of targeted cluster development programs within various sectors of the national economy.

The formulated developments, whose effectiveness was tested during optimization within the industrial cluster of one of the depressed republics of the North Caucasus (Adygea), can be successfully applied in the process of competitive strategy development for the industrial complex and other similar republics of the region.

\section{Conflict of Interest}

The authors confirm the absence of a conflict of interest.

\section{References}

Acuña, M. (2011). Crisis financiera internacional: rupturas y desafíos, Revista de la Universidad del Zulia, 2 (4), 39-58. 
REVISTA DE LA UNIVERSIDAD DEL ZULIA. $3^{a}$ época. Año 11 N² 29, 2020

Viktoriya V. Prokhorova et al. ///Cluster Technology as a basis for the competitive .... 265-275

Afashagova, S. R., Misakov, V. S., \& Ivanov, A. A. (2014). Some tools to stimulate the innovative development of the business environment in the republics of the NorthCaucasian Federal District. Bulletin of the Kabardino-Balkarian Scientific Center of the Russian Academy of Sciences, 5(61), 75-81.

Aloeva, Z. A., \& Misakov, V. S. (2013). The development of adaptation and anti-crisis measures in terms of increasing competition. Bulletin of the Kabardino-Balkarian Scientific Center of the Russian Academy of Sciences, 6-2(56), 30-35.

Ansov, I. (1989). Strategic Management. - M. - Economics, - 175 p.

Artamonova, A. S. (Ed.) (2013). Cluster Policies and Cluster Initiatives: Theory, Methodology, Practice: Monograph. Penza, - 215 p.

Azoev, G. A. (2012). Innovative Nanotechnology Clusters. - M., - 301 p.

Basyuk, A. S., Prokhorova, V. V., Kolomyts, O. N., Shutilov, F. V., \& Anisimov, A. Y. (2016). Administration management in the innovation cluster. International Review of Management and Marketing, 6(6), 180-184.

Bryazgina, E. O. (2016). Industrial clusters as the tool of import substitution stimulation. Economicks, 4, 60-68.

Korchagina, N. A. (2003). Cluster System - the Technology for Company Management Efficiency Improvement: Monograph. Astrakhan: AU publishes. House, - 117 p.

Kushbokova, R. Kh., Shamurzaev, Z. S., \& Misakov, V. S. (2009). Some approaches to innovative potential management of an industrial enterprise. Terra Economicus, 7(4-3), $123-125$.

Lagodyuk, A. K. (2010). Investment Management in Clusters: Modern Aspect. Russian Journal of Entrepreneurship, 10, Part 1, 60-67.

Misakov, A. V., Molamusov, Z. Kh., \& Misakov, V. S. (2016). Some methods of investment activity modeling in industrial enterprises during uncertainty. Economics and Entrepreneurship, 1-2(66), 606-610.

Prokhorova, V. V., Chernikova, V. E., Anopchenko, T. U., Goloshchapova, L. V., \& Kulikova, N. N. (2018). Formation and development of industrial clusters in the socioeconomic regional system. Espacios, 39(31).

Rzhevskaya, E. A. (2012). Clusters as a kind of network structure. Economic systems, 4, 1519.

Vinokurova, Yu. R. The main characteristics and stages of clusters. New in economics and management. - M.: Max PRESS, 12, 72-99. 
REVISTA DE LA UNIVERSIDAD DEL ZULIA. 3e época. Año $11 N^{\circ}$ 29, 2020 Viktoriya V. Prokhorova et al. ///Cluster Technology as a basis for the competitive .... 265-275

Yudanov, Yu. A. (2012). Competition: Theory and Practice: Monograph. - M.: "Scientific publication", - $384 \mathrm{p}$.

Zakharova, E. N., Prokhorova, V. V., Shutilov, F. V., \& Klochko, E. N. (2015). Modern tendencies of cluster development of regional economic systems. Mediterranean Journal of Social Sciences, 6 (5 S3), 154-163. 